\title{
Excavations at San Juan Capistrano, 41BX5, Bexar County, Texas
}

David D. Turner

Follow this and additional works at: https://scholarworks.sfasu.edu/ita

Part of the American Material Culture Commons, Archaeological Anthropology Commons, Environmental Studies Commons, Other American Studies Commons, Other Arts and Humanities Commons, Other History of Art, Architecture, and Archaeology Commons, and the United States History Commons

Tell us how this article helped you.

This Article is brought to you for free and open access by the Center for Regional Heritage Research at SFA ScholarWorks. It has been accepted for inclusion in Index of Texas Archaeology: Open Access Gray Literature from the Lone Star State by an authorized editor of SFA ScholarWorks. For more information, please contact cdsscholarworks@sfasu.edu. 


\section{Excavations at San Juan Capistrano, 41BX5, Bexar County, Texas \\ Creative Commons License \\ (c) (1) \& 8}

This work is licensed under a Creative Commons Attribution-NonCommercial 4.0 International License 


\section{EXCAVATIONS AT SAN JUAN CAPISTRANO, 41 BX 5, BEXAR COUNTY, TEXAS}

David D. Turner

Center for Archaeological Research The University of Texas at San Antonio

Archaeological Survey Report, No. 171 


.






\section{EXCAVATIONS AT SAN JUAN CAPISTRANO, 41 BX 5, BEXAR COUNTY, TEXAS}

David D. Turner

Texas Antiquities Committee Permit No. 658

Center for Archaeological Research The University of Texas at San Antonio ${ }^{\circledR}$ Archaeological Survey Report, No. 171 
The following information is provided in accordance with the General Rules of Practice and Procedure, Chapter 41.11 (Investigative Reports), Texas Antiquities Committee:

1. Type of investigation: archaeological testing at Mission San Juan Capistrano;

2. Project name: Mission San Juan Capistrano Testing, 1986;

3. County: Bexar County, Texas;

4. Principal investigator: Thomas R. Hester; coprincipal investigators: Jack D. Eaton and Anne A. Fox;

5. Name and location of sponsoring agency: San Antonio Missions National Historical Park, San Antonio;

6. Texas Antiquities Committee Permit No. 658;

7. Published by the Center for Archaeological Research, The University of Texas at San Antonio, San Antonio, Texas 78285-0658, 1988.

A list of publications offered by the Center for Archaeological Research can be obtained by sending $\$ 1.00$ to the Center for Archaeological Research, The University of Texas at San Antonio, San Antonio, Texas 78285-0658. 


\section{TABLE OF CONTENTS}

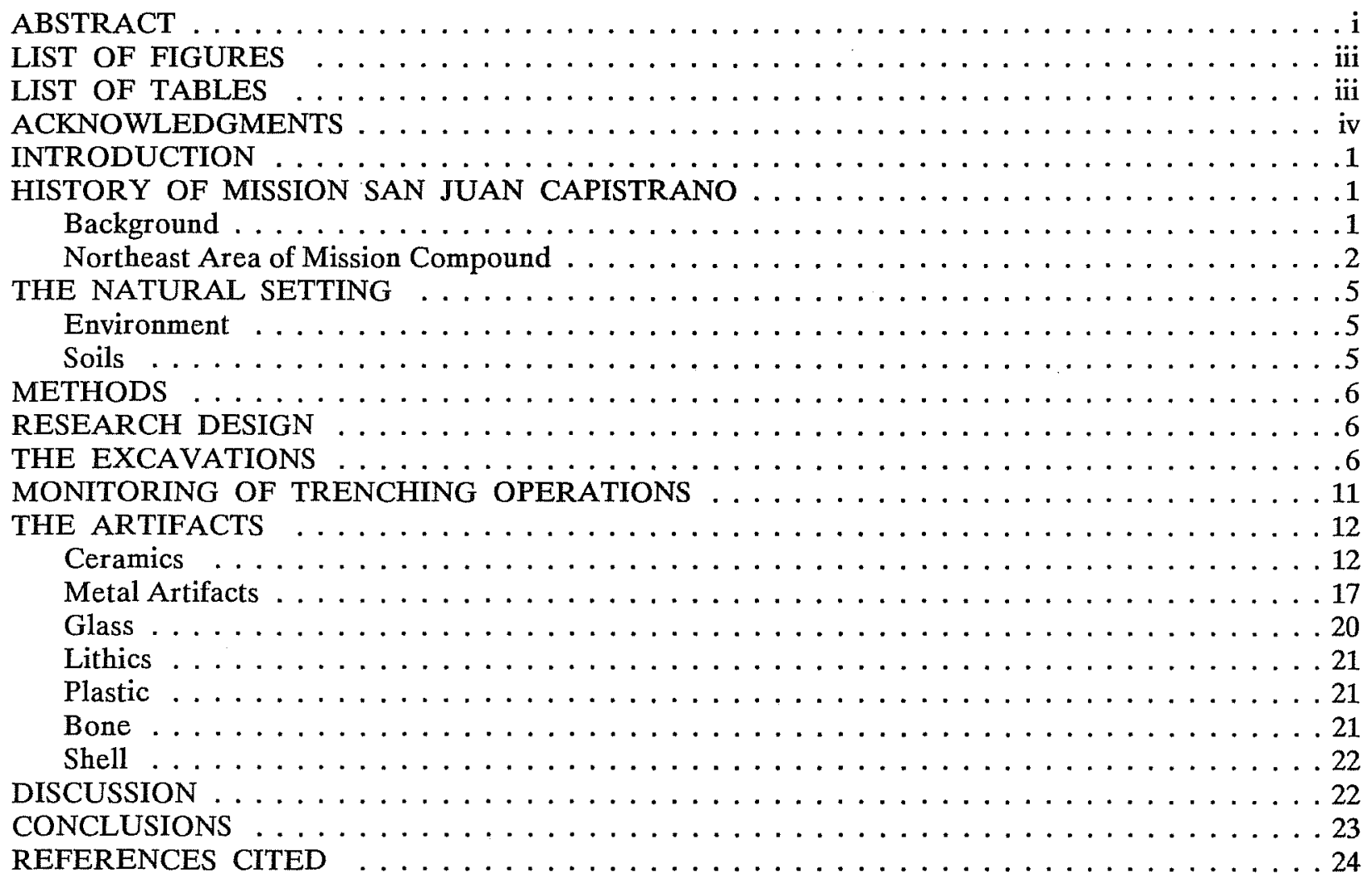




\begin{abstract}
In February 1986, test excavations were conducted outside the north wall of Mission San Juan Capistrano (41 BX 5). This testing was done to determine any potential impact of proposed City Water Board trenching activities on buried structural features. Although no structural remains were found, midden deposits were encountered. This report discusses the artifacts and the identified depositional strata of the midden.
\end{abstract}




\section{LIST OF FIGURES}

1. Plan of Mission San Juan Capistrano, Showing the Locations for the 1967 and 1986 Excavations _ . . .4

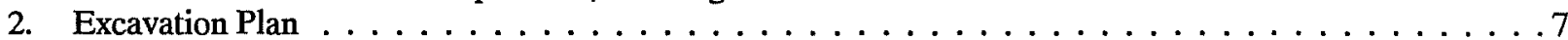

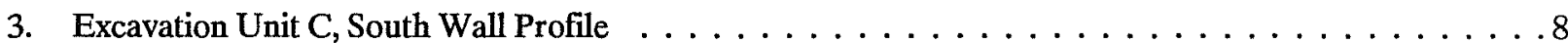

4. Excavation Unit F, South Wall Profile . . . . . . . . . . . . . . . . . . . . . . . 9

5. Excavation Unit $G$, South Wall Profile $\ldots \ldots \ldots \ldots \ldots \ldots \ldots$

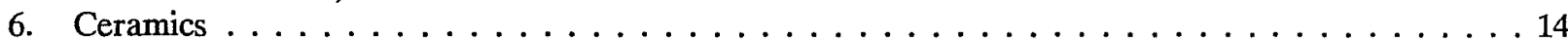

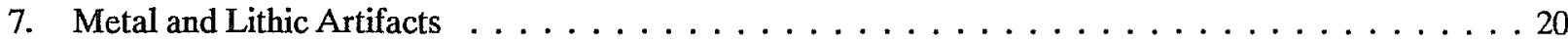

\section{LIST OF TABLES}

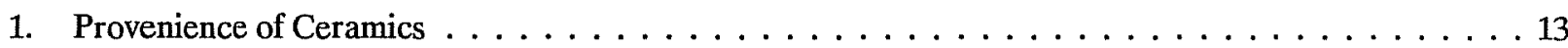




\section{ACKNOWLEDGMENTS}

Participants in the Mission San Juan Capistrano test excavations are staff members of the Center for Archaeological Research. All technical staff participants are currently graduate and undergraduate students in the Anthropology program at The University of Texas at San Antonio.

Anne Fox, research associate at the Center, served as the project director. Anne was present through excavation, monitoring of the trenching operations, laboratory analysis, and report preparation. Without her experience, this project would have been impossible.

Other participants in the test excavations were Cathy Dodt-Ellis, Paul Maslyk, Kelly Scott, Frances Meskill, Bonnie Foster, Phyllis Foster, Duke Smith, Don McEwan, and Jeff Huebner. Jane Robison, resident of San Antonio, also volunteered her time to assist with this phase of the work.

After the test excavations were completed, the City Water Board began the trenching in preparation for the pipeline construction. Monitors of the trenching operations were Joe Labadie and Kelly Scott. Special thanks are extended to the City Water Board crew and their foreman, Mr. Delmar M. Bartay, for their cooperation, interest, and professionalism in handling an unfamiliar situation.

Laboratory analysis and report preparation were conducted by Paul Maslyk, Cathy Dodt-Ellis, Bruce Ellis, Anne Fox, and Kelly Scott, who deserves special mention: Kelly was present through all phases of the work and patiently typed the draft manuscript.

Richard Ahlborn and Dr. Richard Doty of the Smithsonian Institution kindly identified the religious medal and the coin for us.

The patience and professionalism of the National Park Service ranger staff at Mission San Juan Capistrano helped make this project a success. Our thanks to Jill L. Campbell, Georgiana Gilbert, Mike Capps, and Daniel Boling.

We are grateful to Los Compadres de San Antonio Missions National Historical Park for financing the field work and the production of this report.

Finally, very special thanks to my wife, Jeri, for her help in preparing this manuscript. 


\section{INTRODUCTION}

On February 6 and 7, 1986, staff members of the Center for Archaeological Research (CAR) at The University of Texas at San Antonio (UTSA) conducted test excavations outside the north wall and east of the gate at Mission San Juan Capistrano. The purpose of this testing was to determine if proposed City Water Board pipeline construction activities would have an impact on any buried structural or midden features in this area. The investigations were conducted under contract between the CAR-UTSA and the National Park Service, San Antonio Missions National Historical Park (Jose A. Cisneros, letter dated February 4, 1986). The project was financed by Los Compadres de San Antonio Missions National Historical Park.

The field work was done by David D. Turner, field director, under the general supervision of Anne A. Fox, project director. Overall supervision was provided by Thomas $\mathbb{R}$. Hester and Jack D. Eaton, Center director and associate director, respectively.

The testing was done in compliance with the National Historic Preservation Act of 1966 (as amended) and Executive Order 11593. Texas Antiquities Committee Permit No. 658 was obtained for the testing at the mission. Mission San Juan Capistrano is a part of the San Antonio Missions National Historical Park and is listed on the National Register of Historic Places.

No previous archaeological investigations have been conducted in this area with the possible exception by the Works Progress Administration (WPA) who restored the outline of a number of the walls of the mission structures (Schuetz 1968:67). The possibility of disturbing significant structural remains such as outbuildings, which could answer questions regarding mission life, particularly economic activities, was strong enough to warrant archaeological testing prior to any construction trenching.

\section{HISTORY OF MISSION SAN JUAN CAPISTRANO}

\section{BACKGROUND}

Mission San Juan Capistrano was originally established in east Texas as Mission San José de los Nazonis. The Nasoni are currently thought to have been a Caddoan group (Campbell and Campbell 1985:54-55). The east Texas mission was established in 1716 and temporarily abandoned in 1719. Reoccupied in 1721, it was finally abandoned in 1729 , when all attempts to establish missions in east Texas were discontinued. This mission, along with others from east Texas, was moved to the San Antonio River area in 1731 (Schuetz 1968:13). These missions were renamed San Juan Capistrano, La Purísima Concepción de Acuña, and San Francisco de la Espada. Mission San Juan Capistrano was established primarily for four Indian groups: Orejones, Sayopines, Pamaques, and Piguiques (Schuetz 1968:13-14).

Whether or not all of these groups were Coahuiltecan speakers is a matter of some dispute. Campbell and Campbell $(1985: 16-17,77)$ challenge the concept of a "Coahuiltecan culture area" developed by Ruecking $(1953,1954,1955)$ in the 1950s. Campbell and Campbell (1985:16-17) argue that Coahuiltecan was the language adopted for use in the missions by the missionaries, and they identify at least eight language groups (Campbell and Campbell 1985:69). The Pamaque are not thought to have been Coahuiltecan speakers before entering the missions (Campbell and Campbell 1985:35). Campbell and Campbell (1985:34-35, 37-38) point out that the Pamaque and Piguique were amalgamations of other decimated Indian groups. The Pamaque, meaning "people of the south," included remnants of the Camasuqua, Sarapjon, Taguaguan, Tinapihuaya, and Viayan groups. The Piguique included at least one group which was not recorded by its own name in the literature: the Manos de Perro (dog-hands).

The population of the native peoples of Texas had already suffered tremendous loss even before the Spanish began establishing missions in east Texas. Ewers (1973:104-115) suggests that Spanish introduced diseases preceded and accompanied physical contact. Nineteen epidemics are listed by Ewers $(1973: 108)$ for the 
years from 1528 to 1802 . In 1739, small pox and measles nearly depopulated the San Antonio River missions. For that year, Schuetz (1968:37) reports that the Indian population from Mission San Juan Capistrano had declined from 218 to 66 due to death and abandonment. In 1751 and again in 1763, two as yet unidentified diseases helped to depopulate the San Antonio River missions. The 1763 epidemic depleted the mission Indian population by half (Ewers 1973:108). Weddle and Thonhoff (1976:69) suggest that the unknown diseases were a severe form of influenza.

Such problems were part of the mission environment and were not seen (by the missionaries) as insurmountable. Frequent abandonment and return were part of the Indian reaction to the missions. Disease caused abandonment of Mission San Juan Capistrano in 1739; but by 1740, the population was 169 (Schuetz 1968:33). Schuetz (1968:37) reports that Mission San Juan Capistrano was thriving in 1756, with an Indian population of nearly 265 .

The 1750s and 1760s (despite problems with diseases and unfriendly Indians) are seen as the most successful years of mission development (Schuetz 1969:50; Environmental and Cultural Services, Inc. 1982:6-9) as these were the years of stone building and/or renovation at many of the missions. In 1762, Mission San Juan Capistrano reported 847 baptisms, 645 burials, and 51 resident families with 203 persons (Weddle and Thonhoff 1976:136).

The 1770s and 1780s mark the decline of the San Antonio River missions. At Mission San Juan Capistrano, the population in 1783 was 99 , but in 1790 was 21 . Articles of secularization for Mission San Juan Capistrano were drawn up in 1794. The church community, then was visited and inspected by the priest of Mission Espada (Schuetz 1968:53-54), who provided a visita (census report and inventory of goods) for the mission.

The 1809 census of Mission San Juan Capistrano has only 9 men and 11 women listed as heads of families. Schuetz $(1968: 53,56,58)$ believes that the Indians had been absorbed into the greater population of San Antonio.

After secularization, Mission San Juan Capistrano was still used by local residents for, among other things, a source of building stone. The standing structures were used as dwellings. A structure built on the east wall between 1847 and 1890 was used as a house and as a school house in the 1920s and 1930s (Schuetz 1969:226-227). This usage of the mission indicates that the community formed around the old structures. Very limited restoration and preservation efforts were carried out in the late 19th century and early 20 th century.

Limited WPA restoration work was conducted at Mission San Juan Capistrano in the 1930s. On November 10, 1978, Public Law 95-629 was passed by the 95th Congress, providing for the establishment of the San Antonio Missions National Historical Park (Cisneros 1980) of which Mission San Juan Capistrano is part. Mission San Juan Capistrano is jointly administered by the National Park Service and the Catholic Archdiocese of San Antonio. The church continues to serve an active congregation.

\section{NORTHEAST AREA OF MISSION COMPOUND}

The possible date for construction of the north compound wall section east of the north wall gate is a matter of some conjecture. Ivey and Thurber (1984:70-73) state that the entire mission was undergoing a major expansion and renovation in 1772 , and that this section of wall was added sometime after 1775 , but before the complete secularization of the mission lands in 1824. This statement is hard to accept if the visita report of Father Juan Agustín Morfi (Schuetz 1968:53-54) is taken into account. His report describes a mission in economic decline. It would seem that the expense of building a wall would not have been economically feasible at that time.

Schuetz $(1968: 33,34)$ suggests that the wall was constructed between 1756 and 1762 . This is apparently based on the visita reports of Father Francisco Xavier Ortiz in 1756 and Fray Mariano de los Dolores in 1762. 
Ivey and Thurber (1984) present the idea that the original north and east walls of the mission compound delineated a much smaller area, and that the original east wall ran on a line $8^{\circ}$ west of north from the present southeast corner of the compound. If this is the case, then the original defensive perimeter walls would have met at the north wall near the present east side of the north wall gate. Ivey and Thurber (1984:73) state that these early perimeter walls were built ca. 1765 . The argument continues that some remnant of this wall should still underlie the compound and the church on the east side of the compound, Room 26. Schuetz found no trace of this wall during the 1967 excavations (Fig. 1).

If Ivey and Thurber are correct, then the present mission compound was built in three stages. The first stage was the building of the southwest corner of the compound as part of the original convento structure (Fig. 1). The second stage would have been the addition of the early north and east perimeter walls in 1765 . The third stage would have been the demolition of these walls and the construction of the present north and east curtain walls.

Excavations at Rancho de las Cabras demonstrated that the gate side areas of the compound were used as trash dumps. However, at Rancho de las Cabras pits were dug for the disposal of garbage (Ivey and Fox 1981:7, 27; Ivey 1983:10). The 1986 test excavations at Mission San Juan Capistrano indicate that the entire area outside the east section of the north wall gate was used as a trash dump. This indicates that a different set of trash disposal habits were in use at the mission than at Rancho de las Cabras. Gate side middens have also been located at Mission San José (Hafernik and Fox 1984:5, Fig. 2), and at the Alamo (Fox, Bass, and Hester 1976:43, 69).

The building of the wall logically dates the beginning of artifact deposition in the midden area outside the compound. The date of the wall construction is the latter half of the 18 th century. Whether the wall was built ca. 1756 or ca. 1775 , the types of artifacts found would not be recognizably different, since analysis of Spanish colonial period artifacts has not yet been able to provide a resolution finer than 50 years. The resolution of the issue of an as yet-unlocated early north and east perimeter wall, built ca. 1765, must await a future archaeological investigation inside the mission compound.

After secularization of the Mission San Juan Capistrano properties in 1824, much interest was shown in the plots of land in the northeast section of the compound. Sections of the north wall east of the north gate were included in transactions six times among at least five property owners between 1824 and 1890 (Schuetz 1968:64-66; Almaraz 1982:41-43; Ivey and Thurber 1984:23-25). These transactions for lots may have included houses or other structures. An 1847 land office plat, the Saucedo plat filed in 1873, and the William Corner 1890 plat (Schuetz 1968:Figs. 5,a,b; 7) show a double wall line on the north and east walls. These double lines extend from the north wall gate to the church building on the east side of the compound, possibly indicating extant structures. However, it is also possible that they simply indicate a surveyed property line boundary.

Mission Record No. 15 for 1824 does not show any indication of a double wall line existing on the northeast wall section (Schuetz 1968:227). Bachiller Francisco Maynes bought the northeast wall corner of the compound in 1824. Maynes had the right to salvage stone from the defensive perimeter wall in his plot (Almaraz 1982:42). Whether this affected the existence of structure walls inside or adjoining this section of the compound wall is uncertain.

Ivey and Thurber (1984:25) state that a house was standing between 1827 and 1853 immediately east of the north gate. However, the 1890 plat by W. Corner does not record this building as still standing at that time.

The possibility of structures outside the compound wall is reported by Schuetz (1968:228). Since a forge and a barn, possibly the same structure, were not conclusively identified in the 1967 excavations, it is conceivable that these buildings were outside the compound walls. Schuetz (1968:228) felt that the location of the barn could be behind the church building or along the north wall. The major reason Schuetz addressed the possibility of structures outside the northeast section of the wall was because of a painting by the Romantic School painter Hermann Lungkwitz, painted during the 1850s (Schuetz 1968:Plate 1). This painting shows a structure standing at the corner of the north and east walls, as well as a roofed structure on the east side of the gate. Given the confusing perspective of the painting, the structures shown could be attached to the 


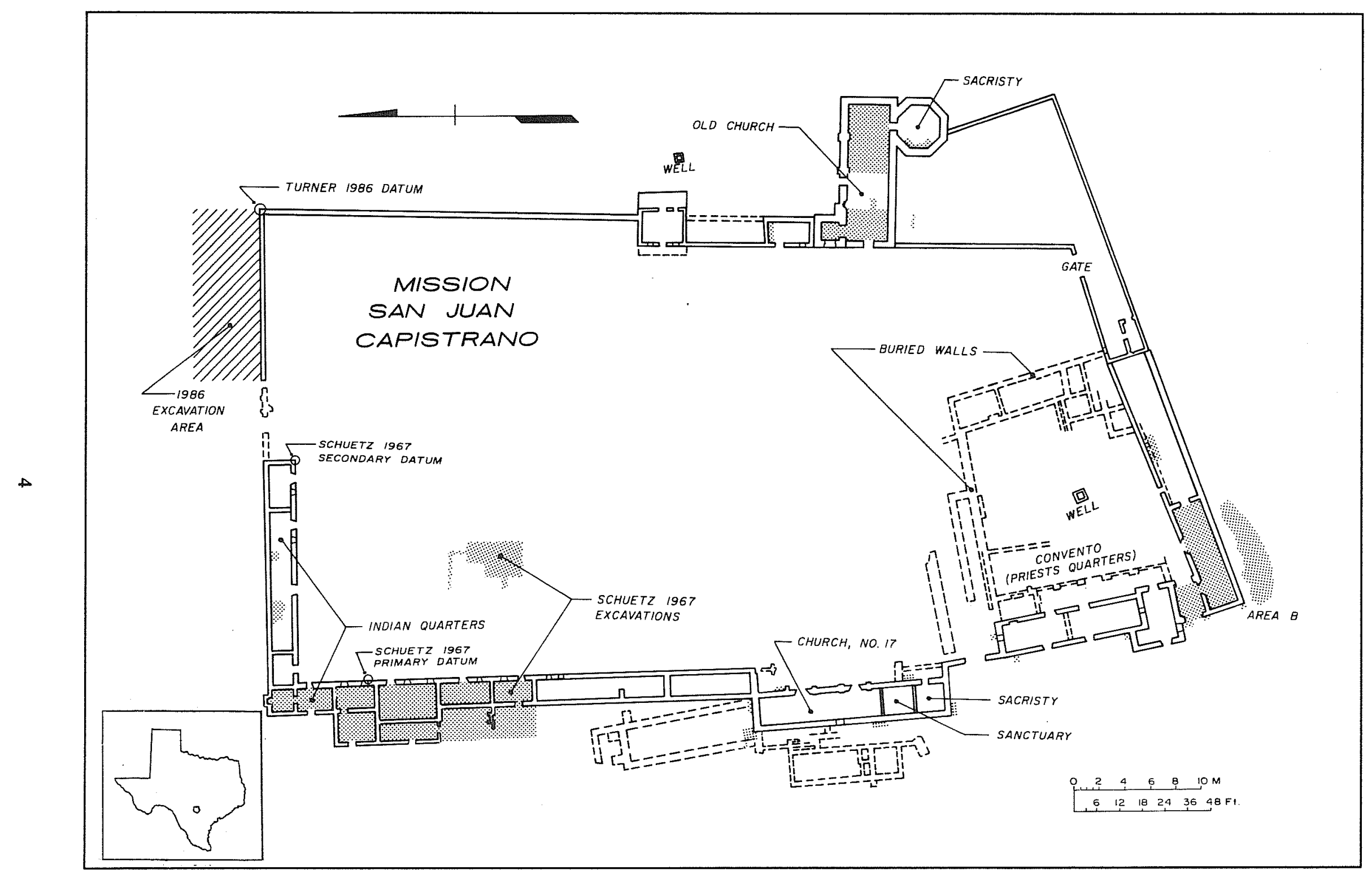

Figure 1. Plan of Mission San Juan Capistrano, Showing the Locations for the 1967 and 1986 Excavations. 
wall or free standing inside or outside the north wall. One problem with using the Lungkwitz painting is that it is, after all, a work of art with all that term implies, and as such should not be given the same weight in guiding scientific and historic research as is given to property deeds or the relaciones (narratives, often published by church and secular officials) of the priests. The 1986 testing project determined that the painting is, at best, misleading.

\section{THE NATURAL SETTING}

\section{ENVIRONMENT}

Early descriptions of the San Antonio River area paint a picture of a rich, fertile land teeming with wildlife. The Solis diary of 1767 and the Morfi 1777 diary (Schuetz 1968:10) contain descriptions of large mesquite trees, groves of walnut and live oak, and patches of wild grapes in this area. Deer, javelina, and numerous types of waterfowl lived along the river.

The river was a source of life as well as great difficulty for the Spanish settlers. The San Antonio River has a flood recurrence interval of approximately one decade (Environmental and Cultural Services, Inc. 1982). Mission San Juan Capistrano is located $20 \mathrm{~m}$ from the old river channel. Several times during the mission period, Mission San Juan Capistrano was flooded.

In 1972 and 1973 the San Antonio River was channeled to limit flooding. This resulted in a changed appearance and water flow rate (Southwest Regional Office, National Park Service 1981:49).

Current land use around Mission San Juan Capistrano continues much the same as in 1731: a small residential community surrounded by farmland.

\section{SOILS}

Mission San Juan Capistrano was built on Karnes clay loam, and the fields, for the most part, were located on the Frio soils common along this area of the San Antonio River (Taylor, Hailey, and Richmond 1966:Map Sheet 71). The artifact-bearing soil deposits consist of a loamy clay soil which ranges in color from dark gray brown (10 YR 4/2) to light brown gray (3/2 to $10 \mathrm{YR} 5 / 3)$. At an average depth of 5.5 to 6 feet, is a lightcolored marl with a Munsell (Munsell Soil Color Charts 1975) value of 10 YR 8/3. Gravels located at this depth and throughout the excavation process were water smoothed and covered with lime carbonates.

Karnes loamy clays occur along low river and stream terraces as a component of the Venus-Frio-Trinity association (Taylor, Hailey, and Richmond 1966:6 and general soils map). This soil association occupies bottomlands and low terraces along rivers and their tributary streams. These clays are deep, calcareous, and develop in alluvium. The Karnes series soils and the Frio series soils are described in detail by Taylor, Hailey, and Richmond (1966:16, 23). 


\section{METHODS}

Test excavations were conducted according to the archaeological procedures of Fladmark (1978:83-111) and Hemion (1983:7-17).

A transit and stadia were used to determine the exact location of the City Water Board trench line which ran west to east, parallel to the north compound wall of the mission. Beginning surface elevations of each excavation unit were taken with transit and stadia as were the last elevations before the trench was filled. These readings were tied into the primary and secondary site datum established by Schuetz during the 1967 excavations (Fig. 1). Excavators used line levels to monitor depth while working. Excavation was conducted in arbitrary $10-\mathrm{cm}$ levels in $1-\mathrm{m}^{2}$ units. Shovels and trowels were used, and all excavated material was passed through 1/4-inch mesh screens. Each excavator recorded information on soils, excavated artifacts, and other material. These excavation level notes were filed with a daily master log maintained by the field director. Artifacts recovered were bagged according to artifact category, excavation unit and level, and returned to the laboratory for cleaning and analysis.

Laboratory procedures started with the cleaning and logging of the recovered artifacts. Artifacts were separated, counted, and weighed by category. The artifacts were identified by comparison with the extensive artifact collections at the CAR-UTSA. These collections include the material excavated during Schuetz' 1967 excavations at Mission San Juan Capistrano, as well as collections from the Alamo and the Rancho de las Cabras excavations. Site reports and reports on historic-manufacturing technologies were consulted to corroborate the artifact identifications. All artifacts, field notes, and other pertinent data associated with this work are curated at the CAR-UTSA.

\section{RESEARCH DESIGN}

The terms of the contract gave the CAR investigative team two working days in the field to examine the northeast wall and gate area, and nearly three working days for laboratory analysis of the excavated material. Thus, the design of this study was focused on the objective of gaining as much useful information as possible under the given limited amount of time.

The test units were laid out along the centerline of the surveyed City Water Board trench route. Since the City Water Board excavations were to be confined to linear trenches of 22-24 inches wide, the archaeological investigation focused specifically on the area to be disturbed. The number of test units excavated was based on available manpower.

The City Water Board also trenched along a recently laid asphalt roadway on the east side of the mission. The roadway was built as an access to the parking area currently behind (south of) the mission compound. This trench was cut in the area disturbed by leveling and roadbed construction activities, therefore no archaeological testing was proposed. Visual monitoring of the City Water Board activities was conducted in this area by the CAR excavation team volunteers. The purpose of this monitoring was to utilize an opportunity to obtain the maximum amount of cultural information possible from the open trenches.

\section{THE EXCAVATIONS}

Excavators opened five $1-\mathrm{m}^{2}$ units (Fig. 2) in the testing area. These units straddled the City Water Board trench line. Undisturbed sterile clays were encountered 50 to $60 \mathrm{~cm}$ below the surface. The maximum depth for archaeological testing was $80 \mathrm{~cm}$ below the surface. Since the sterile clays were undisturbed, further excavation was deemed unnecessary. Two of the units exposed a hard-packed rocky layer mixed with caliche and late period artifacts. 


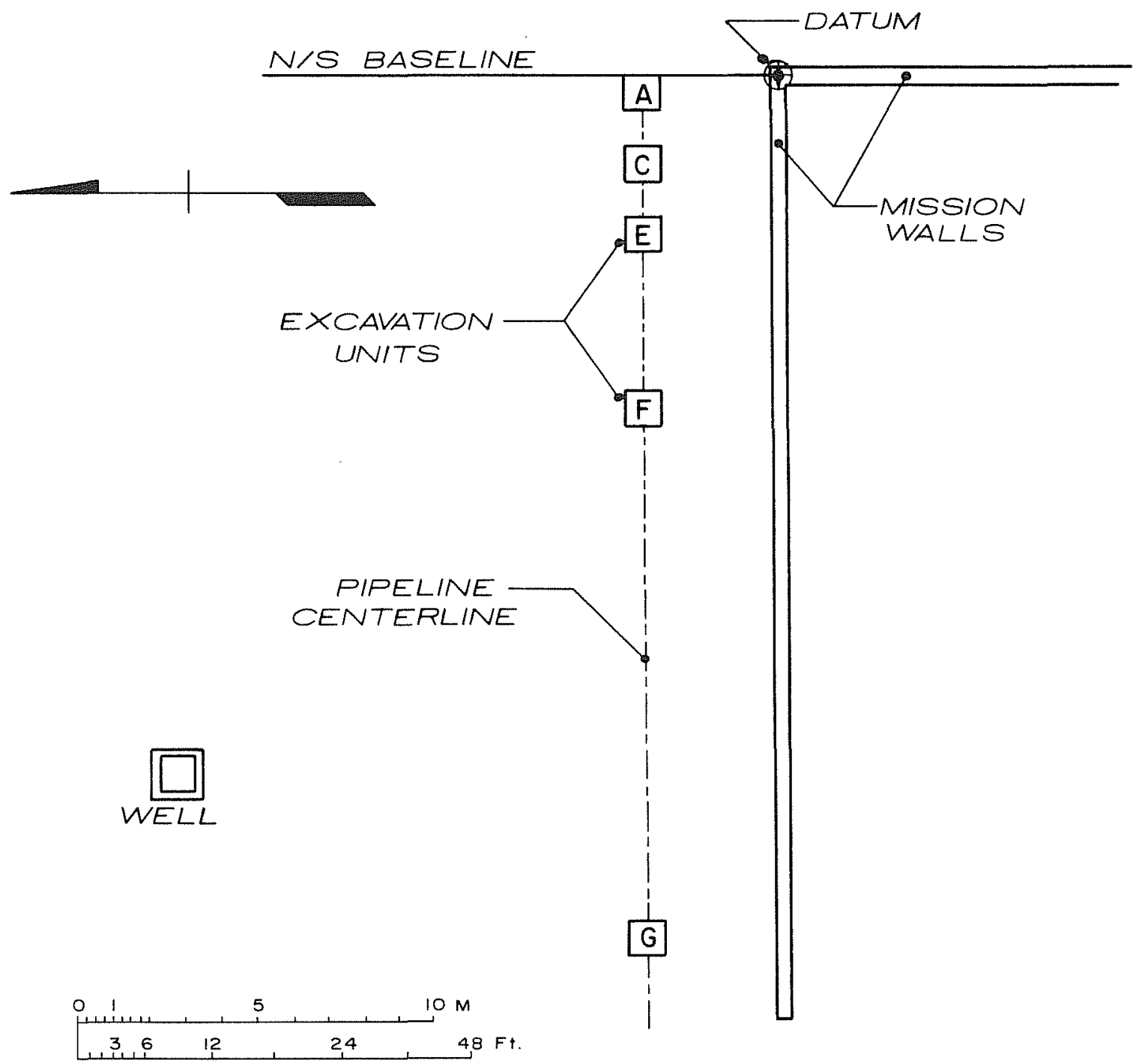

Figure 2. Excavation Plan. Excavation units A, C, E, F, and G are indicated.

The topsoil in the excavation area was very hard packed. Vegetation, such as common garden weeds and clover, was present. Parallel linear patches of hard-packed earth betrayed vehicle usage. These were very noticeable at the west end of the study area by the north gate. Until February 1986, this area was used as a roadway and parking area by parishioners on Sundays and religious holidays. The area is to be completely fenced after the City Water Board completes its pipeline construction in an effort to minimize vehicular traffic near the fragile walls of the mission (National Park Service rangers at Mission San Juan Capistrano, personal communication). 
The excavations were conducted in $10-\mathrm{cm}$ arbitrary levels. This method provided sufficient resolution to identify three cultural strata in the midden deposits. The artifacts revealed a long-term deposition sequence which began in the latter half of the 18th century and continued until 1986. The midden deposition surrounding the north and east wall sections began sometime between 1756 and 1760 . The entire outside area of the wall was used as a trash dump with a marked preference near the east end of the gate.

Use of the area as a midden was not as intensive in the latter half of the 19th century, and during the 20th century the area was used as a roadway. The hard-packed dirt path was the result of vehicular usage over a heterogeneous layer of dumped rocks interspersed with artifacts. The rock material is thought to have been dumped during the WPA restoration work during the 1930s.

Stratum $I$ is represented by excavation Levels 1 and $2(0-20 \mathrm{~cm})$. In Figures 3-5, these excavation levels are labeled "A" and "B." The Munsell values for "A" range from 10 YR 4/2 to 10 YR 4/3. The Munsell value for " $B$ " is $10 \mathrm{YR} 3 / 2$. This cultural stratum is characterized by late 19 th-century/20th-century bottle glass, nails, wire, and a ceramics assemblage dominated by undecorated whitewares. This stratum also included a layer of rocks $10-14 \mathrm{~cm}$ thick, mixed with 19 th-century and 20 th-century artifacts. This tightly packed rock layer occurred within 3 to $5 \mathrm{~cm}$ of the surface (labeled as "B" in Figs. 3-5). Excavation in this layer was moderately difficult. The rock layer included broken building stone similar to that found in the walls of other mission structures; also, numerous river-smoothed gravels and some low-grade chert nodules were noted in this layer. The rock was fractured into sizes ranging from pea-sized gravel to fist-sized chunks. The heterogeneous collection of the materials in this rocky layer eliminates the possibility that this is a floor. In the bottom part of this layer, the cultural material was mixed with light-colored caliche.

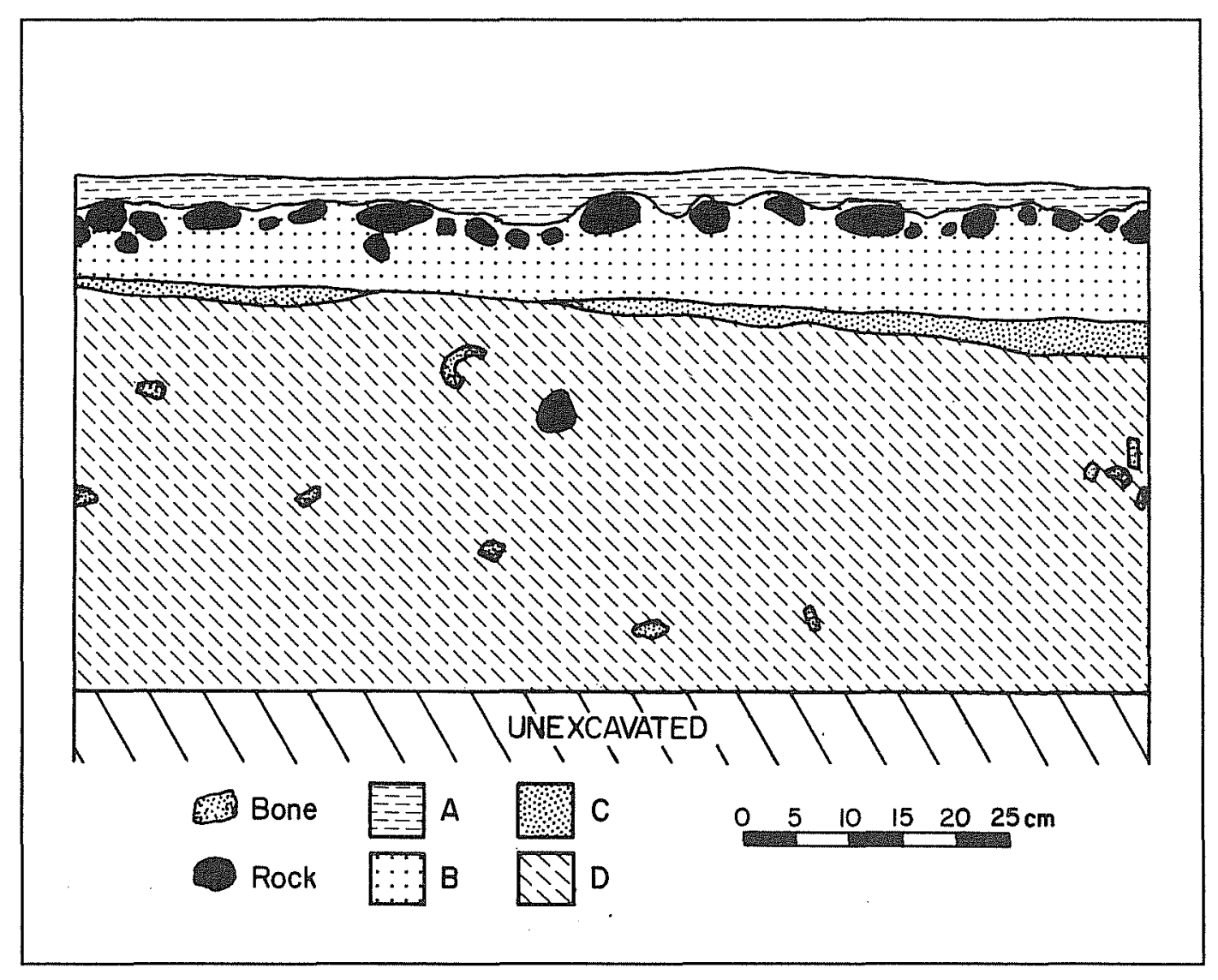

Figure 3. Excavation Unit C, South Wall Profile. 

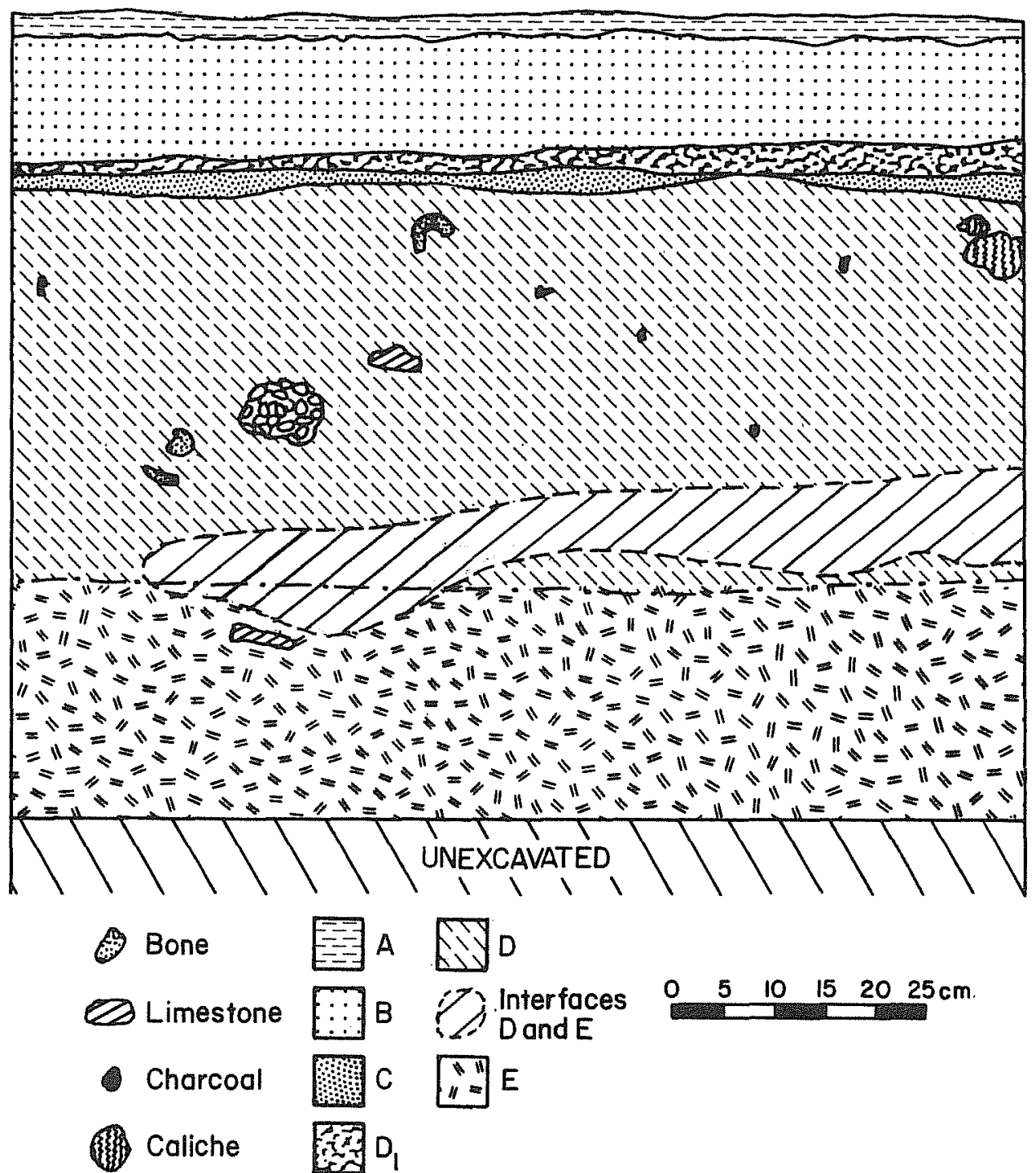

Gravel

Figure 4. Excavation Unit F, South Wall Profile.

Sixty-eight percent of the glass sherds found in the 1986 test excavations were from excavation Levels 1 and 2. Also found in stratum I were 51 sherds of undecorated whiteware and 69 fragments of metal. Contrastively, in stratum II, only 11 metal fragments were found, and in stratum III, only one coin was found.

The artifacts were excavated from a portion of a driveway that once connected to the main road which entered the mission compound. The hardness of the deposits, along with the presence of mixed-in artifacts, indicates that the roadbed may have been laid by usage rather than intentionally constructed. The roadway leading into the compound was fenced off after 1976. 


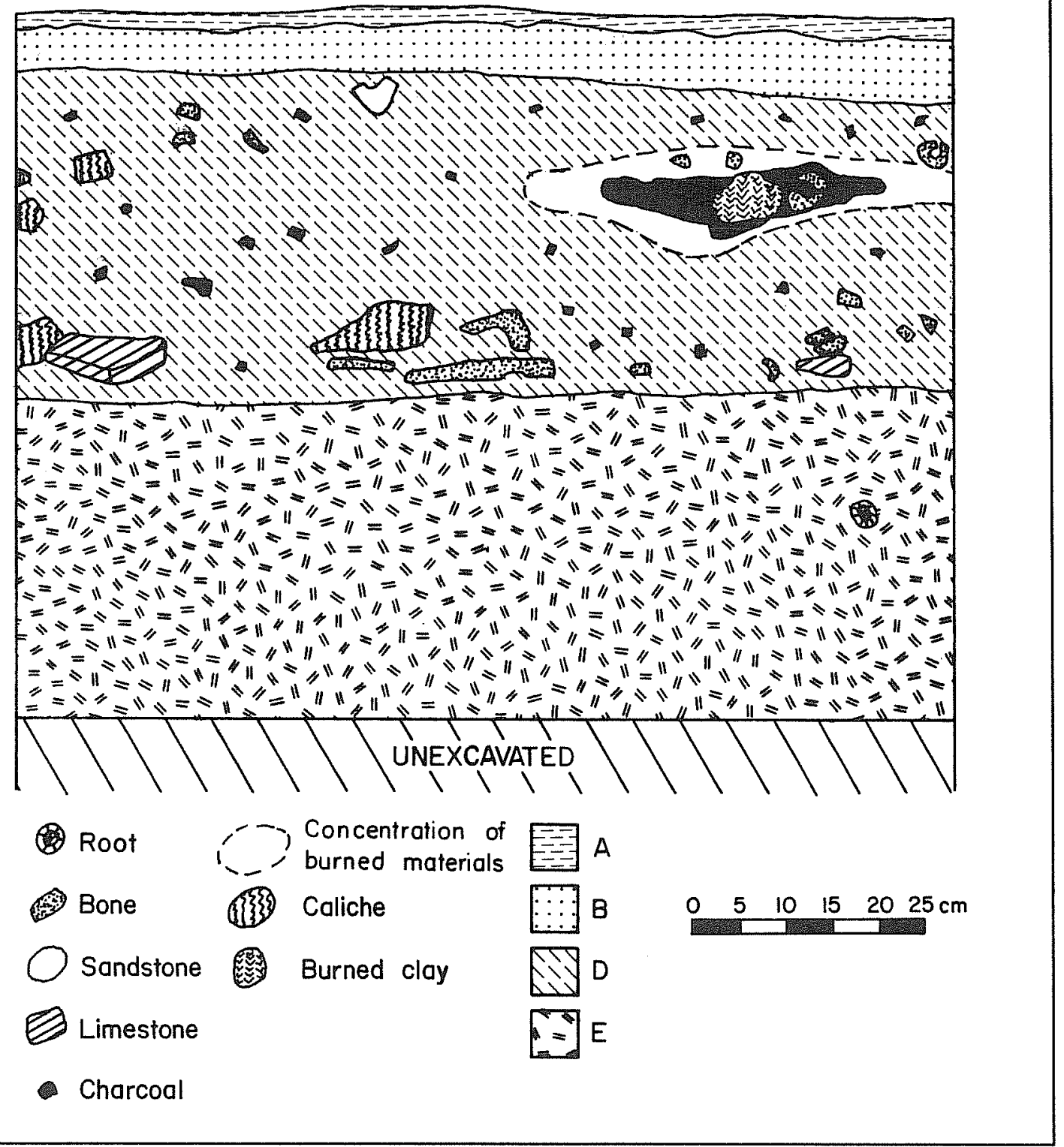

Figure 5. Excavation Unit G, South Wall Profile.

Stratum II was defined by excavation Levels 3 and $4(20-40 \mathrm{~cm})$. In Figures 3 and 4 , this cultural stratum is labeled "C," "D," and " $D_{1}$." The Munsell value for " $C$ " is 10 YR 5/3; for " $D$," 10 YR $3 / 2$ and 10 YR 5/3, and for " $D_{1}$," 10 YR 3/2. Stratum II dates from the 1850s to the 1930s. This cultural stratum is characterized by the presence of a wide variety of ceramics, but Goliad ware was dominant; 99 of the 121 sherds of Goliad ware recovered during these excavations were found in Levels 3 and 4. Nineteen of the 23 Puebla Blue-onWhite wares, 23 of the 33 sandy paste lead glaze ware sherds, and 11 of the 23 burnished redware sherds were found in stratum II. Forty-one sherds of various hard paste whiteware types were also present in this stratum. Only $32 \%$ ( 66 sherds) of the glass fragments were found in stratum II. The lithic material from this stratum includes a Guerrero biface found in Unit F, Level 3. Other items found in this stratum were four square cut 
nail fragments; a brass button cover, stamped with a floral design; a copper pendant with a clear glass set; and a tentatively identified cabestrillo. Metal artifacts were noticeably rare in stratum II.

The artifact assemblage from excavation Levels 5 and $6(40-60 \mathrm{~cm})$ represents the early years of the Spanish colonial period (labeled " $E$ " in Figs. 4 and 5). The Munsell value for this stratum is $10 \mathrm{YR} 3 / 2$. The artifacts collected from these levels are dominated by Spanish colonial period redwares. Three lithic artifacts, a Guerrero biface and two platform flakes, and one metal artifact were also recovered in stratum III.

The exclusive presence of central Mexico and locally made wares in stratum III suggests that other ceramics such as the hard paste whitewares were not available at this time. No glass was found in Levels 5 and 6 . Stratum III is the deepest cultural stratum identified, and is dated 1756-1762 through the early 19th century to the Republic period in the 1830s.

Excavation Unit G, at the west end of the operations area, produced most of the artifacts and animal bone. Unit $\mathrm{G}$ also produced the only burned bone recovered during the test excavations. The burned material was not associated with a pit or hearth. The burned material consisted of 10 fragments of bone $(21.91 \mathrm{~g})$, charcoal, and some clay lumps. The surrounding clays in which the material was located were not thermally altered. The pocket of burned material represents an episode of hearth cleaning, and not a primary usage. This unit closest to the gate indicates, by sheer weight of materials, that the area was a preferred dump area.

\section{MONITORING OF TRENCHING OPERATIONS}

In addition to the controlled excavations, monitoring was conducted by the CAR on the east side of the mission where the City Water Board was trenching. The midden deposit found in this area was disturbed by the City Water Board trench which averaged 5.5 to 6 feet deep and 22 inches to 24 inches wide. The midden is extensive, and the City Water Board work only disrupted a limited section. The profiles revealed that the midden deposit extends north and south of the trenching operation.

During all City Water Board trenching activities, members of the CAR excavation team were present to monitor the operation. The strata revealed during the trenching were consistent with those revealed during the stratigraphically controlled test excavations. Artifacts recovered during this trenching operation include hard paste whitewares, modern bottle glass, plastic corkers, an unidentified metal strap, and miscellaneous unidentifiable animal bone fragments. Artifacts were not removed from the profiles, nor was the trenching operation backdirt screened for artifacts, although some that were visible in the piles were collected, bagged, logged, and returned to the laboratory for analysis.

The City Water Board trench line turned to the south at the asphalt road currently passing the east side of the compound. This trenching operation was also monitored by members of the CAR excavation team. Some artifacts were found, but no artifact-bearing strata were identified. Many stream-rolled cobbles and gravels were noted, along with a few building stones and other rocks. No structural remains or midden features were identified in this north to south trench. If structures did exist outside the northeast wall, they did not extend 12 feet north of it. 


\section{THE ARTIFACTS}

The artifacts recovered during the excavations are divided into the following categories: ceramics, glass, metal, lithics, plastic, bone, and shell.

\section{CERAMICS}

The ceramic fragments ( 447 sherds; $940.87 \mathrm{~g}$ ) were mostly miscellaneous body sherds. A few rim sherds were recovered, but the very small fragments do not reveal a specific vessel shape. Foot ring sherds from at least two majolica cups are in the collection.

Despite the lack of diagnostic fragments for vessel shapes, the ceramic sherds provide some chronology for the cultural strata at the site. The fragments represent types which have been found at other San Antonio mission sites such as San Antonio de Valero (Alamo), Concepcion, and Schuetz' 1967 excavations at San Juan Capistrano. The ceramics define a long-term deposit starting in the Spanish colonial period and continuing to the present. The types of ceramics collected are discussed next and are listed by provenience on Table 1.

\section{GOLLAD WARE}

A total of 121 sherds (317.66 g) of Goliad ware was collected (one sherd specimen is shown in Fig. 6,a). Goliad ware is a thick-bodied, bone-tempered ware which is shaped by hand. It is associated with mission Indians and is generally considered diagnostic of the Spanish colonial period. This ware was made in a local manufacturing tradition related to the Leon Plain tradition (Scurlock and Fox 1977:55; Eaton 1980:29-30; Ivey and Fox 1981:31). Goliad ware has been recovered from the Alamo (Greer 1967:15-16; Eaton 1980:2930), at Mission San José (Clark 1974:76), at Mission Concepción (Scurlock and Fox 1977:55), and at Rancho de las Cabras (Ivey and Fox 1981:31).

\section{BURNISHED REDWARE}

At least two types of a thin-walled, wheel-thrown red paste ware are present in the artifact assemblage. The first, a burnished type with no decoration, is represented by 23 sherds $(59.60 \mathrm{~g})$. This same type was noted in excavations at the Alamo (Greer 1967:16-18), Mission San José (Clark 1974:77), Mission Concepción (Scurlock and Fox 1977:56), and at Rancho de las Cabras (Taylor and Fox 1985:27).

Galera, the second type of redware, represented by five sherds $(5.8 \mathrm{~g})$, is a glazed and decorated ware. Galera ware is a thin-walled, utilitarian ware that first appeared in Texas ca. 1750 (Ivey and Fox 1981:31). One body sherd is shown in Figure 6,e.

A third type of redware, represented by 33 sherds $(137.97 \mathrm{~g})$, is a thick-walled, utilitarian ware made of a very sandy, orange to red colored paste and glazed with a greenish yellow lead glaze. This sandy paste lead glaze variety has been found in the 1967 Mission San Juan Capistrano excavations (Schuetz 1969:52-53), as well as at Mission San Jose (Clark 1974:77), at the Alamo (Greer 1967:20-21; Eaton 1980:30), and at Rancho de las Cabras (Ivey and Fox 1981:34). The sandy paste lead glaze wares were common throughout the 18th century. One sherd is shown in Figure 6,g.

Most of the redwares in the collection are utilitarian vessels. The burnished redwares and the Galera wares represent trade contacts with central Mexico pottery-manufacturing centers during the Spanish colonial period. 
TABLE 1. PROVENIENCE OF CERAMICS

\begin{tabular}{|c|c|c|c|c|c|c|c|c|c|c|c|c|c|c|c|c|c|c|c|c|c|}
\hline & & & & & & & Maj & olica & & & & & ite $\mathrm{Pa}$ & ste V & Nares & & & Other & Cer & ramics & \\
\hline $\begin{array}{l}\text { 志 } \\
\end{array}$ & క్ & 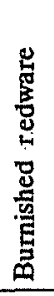 & हू & 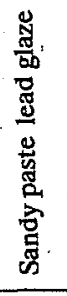 & 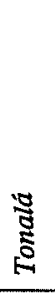 & 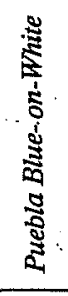 & 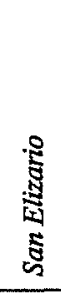 & 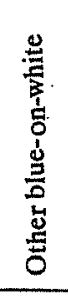 & 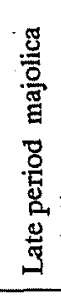 & 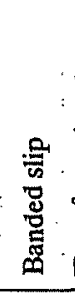 & 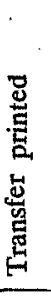 & $\begin{array}{l}\stackrel{\mathscr{J}}{D} \\
\vec{D} \\
\vec{I} \\
\end{array}$ & 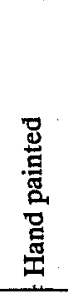 & $\begin{array}{l}\text { 茄 } \\
\text { 总 } \\
\text { 号 }\end{array}$ & 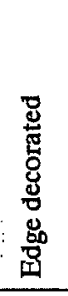 & 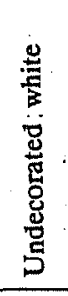 & 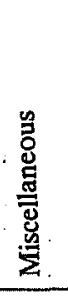 & 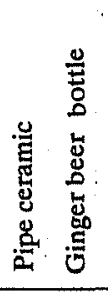 & 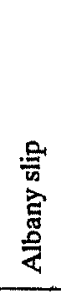 & 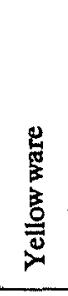 & $\begin{array}{l}\text { ज्ञ } \\
0 \\
\end{array}$ \\
\hline A 1 & & & & & & & & & & 2 & & 1 & 2 & & & 3 & & 1 & & & 9 \\
\hline C 1 & & 1 & & & & & & 1 & & 1 & & 1 & 2 & & 9 & & & 1 & & & 16 \\
\hline C 2 & 3 & 4 & & & & & & & & 1 & & 1 & 8 & & & 11 & & & & 1 & 29 \\
\hline C 3 & 9 & & & 1 & & 11 & & & & & & 2 & 3 & 1 & & 4 & & & & & 31 \\
\hline C 4 & 43 & 1 & 2 & 1 & & 5 & 1 & & 6 & & & & & & & & & & & & 59 \\
\hline C 5 & 2 & 1 & & & & & & & & & & & & & & & & & & & 3 \\
\hline E 1 & & & & & & & & & & & & & 2 & & & 7 & & & 2 & 1 & 12 \\
\hline E 2 & & & 1 & & & & & & 3 & 6 & 3 & & 2 & 3 & & 18 & & & 1 & 3 & 40 \\
\hline F 1 & & 1 & & & & & & & & & & & 1 & 2 & & 8 & & & & 1 & 13 \\
\hline F 2 & & 1 & & 3 & & & 1 & & & & 2 & & 16 & 4 & & 17 & 3 & & & 2 & 49 \\
\hline F 3 & & 2 & & 2 & & & & & & 1 & 2 & & 5 & 3 & 3 & 18 & & & & & 36 \\
\hline F 4 & 3 & & & 2 & 1 & & & & & & & & 1 & & & & & & & & 7 \\
\hline F 5 & 1 & & & 1 & & 1 & & & & & & & & & & & & & & & 3 \\
\hline F 6 & & & & & & 1 & & & 1 & & & & & & & & & & & & 2 \\
\hline G 1 & 6 & & & 2 & & & & & & & & 1 & 1 & 1 & & 3 & 3 & & 1 & 1 & 19 \\
\hline G 2 & 9 & 2 & 1 & 2 & & 2 & & & 7 & & 1 & & & & & 3 & & 1 & 2 & & 30 \\
\hline G 3 & 10 & & 1 & 7 & 1 & 3 & & 1 & 4 & & & & & 1 & & & & & & & 28 \\
\hline G 4 & 34 & 8 & & 10 & & & 1 & & 1 & & & & & & & & 1 & & & & 55 \\
\hline G 5 & 1 & 2 & & 2 & 1 & & & & & & & & & & & & & & & & 6 \\
\hline
\end{tabular}

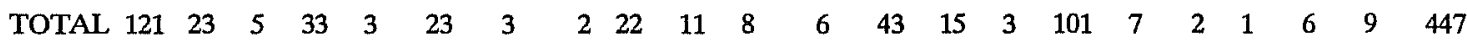




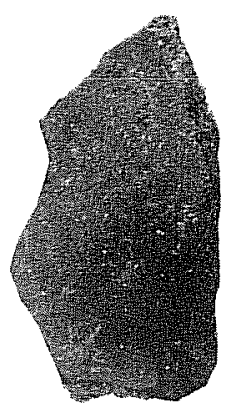

a

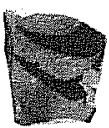

e

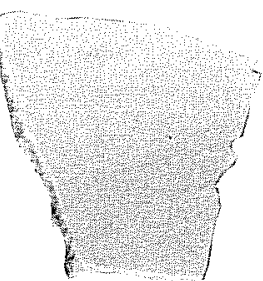

h

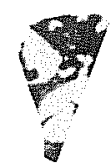

I

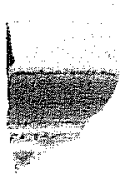

b

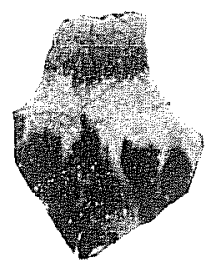

c

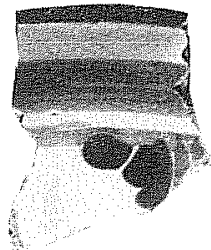

d

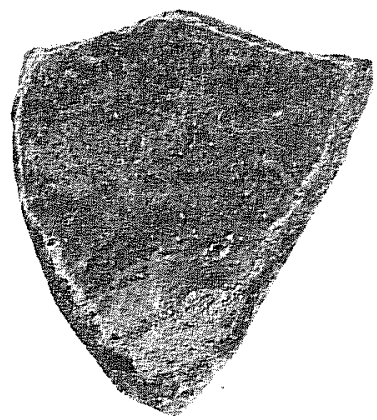

g
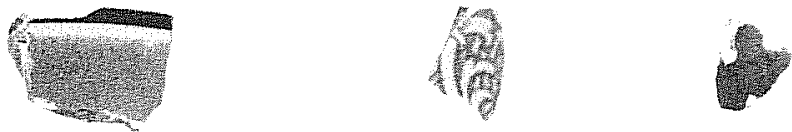

k

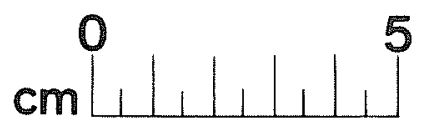

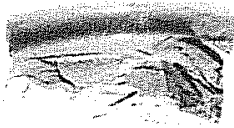

m

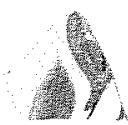

n

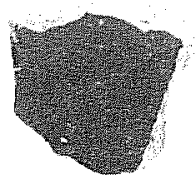

0

Figure 6. Ceramics. a, Goliad ware, Unit G, Level 2; b, San Elizario, rimsherd, Unit C, Level 3; c, unidentified blue-on-white majolica, Unit G, Level 3; d, Puebla Blue-on-White rimsherd, Unit C, Level 3; e, Galera body sherd, painted design, Unit E, Level 2; $f$, Tonalá leg or handle fragment, Unit F, Level 4; g, sandy paste lead glaze ware, Unit C, Level 3; h, late period majolica, undecorated, Unit C, Level 3; i, banded slip ware, Unit E, Level 2; j, transfer print ware, Unit E, Level 2; k, flow blue transfer print ware, Unit B, Level 1; 1, sponged ware, Unit $\mathrm{C}$, Level 3; $\mathrm{m}$, yellow ware rimsherd or large jar or crock, Unit $\mathrm{E}$, Level 2; $\mathrm{n}$, hand-painted floral motif with blue and green leaves, Unit E, Level 2; o, stoneware, Albany slip, Unit G, Level 1. 


\section{TONALA BURNISHED WARE}

Three sherds $(3.52 \mathrm{~g})$ of Tonalá burnished ware were recovered. One sherd is shown in Figure 6,f. Tonalá burnished ware is thin-walled and was manufactured throughout the 18th century and into the 19th century. The type is thought to be diagnostic of a Spanish colonial period site. It was found in mission period context at San Antonio de Valero (Eaton 1980:30). Tonalá was a status ware and appears in very small quantities in the San Antonio mission sites. Schuetz (1969:52) recovered a few Tonala burnished ware sherds in the 1967 excavations at Mission San Juan Capistrano.

\section{MAJOLICA OR TIN-ENAMELED WARE}

Majolica is a term used to describe tin-enameled central Mexico wares manufactured during the 17th, 18th, and early 19 th centuries. Majolica wares are wheel-made with a soft, porous paste. The paste of a sherd can be yellow, buff, or red (Goggin 1968:3). The designs, if present, are hand painted under the transparent glaze. These wares represent a number of pottery-manufacturing traditions in central Mexico. The most notable in this collection is the Puebla Blue-on-White wares, which enjoyed a peak of popularity in the latter half of the 18th century (May 1975:60-62). The tradition contained a number of decorative motifs, at least two of which were recovered during these excavations. One rimsherd is shown in Figure 6,d.

The Puebla Blue-on-White decorative motif of a stylized floral design is represented by 23 sherds ( $31.14 \mathrm{~g})$. This type of ware was most commonly shipped to the northern colonies during the 18th century. Puebla Blueon-White sherds also have been found at the Alamo (Fox, Bass, and Hester 1976:49-52), at Mission San José (Clark 1974:82), at Mission Concepción (Scurlock and Fox 1977:57), and at Rancho de las Cabras (Taylor and Fox 1985:30-31).

Another type of Puebla Blue-on-White ware represented by three sherds ( $3.7 \mathrm{~g}$ ) is the San Elizario type, which was popular during the latter half of the 18th century. San Elizario is painted with a floral motif, but, in addition, the design elements are highlighted with brown lines and accents. These wares were at a peak of popularity from 1760 to 1800 (Ivey and Fox 1981:35). One sherd is shown in Figure 6,b.

Two sherds $(5.6 \mathrm{~g})$ with an unidentified blue-on-white decorative motif were also recovered. One sherd is shown in Figure 6,c.

The remaining 22 sherds ( $48.93 \mathrm{~g}$ ) represent an undecorated, thick-walled, very pale green majolica, which is diagnostic of the latter part of the 19th century and early 20th century. This type is wheel-made with a red paste. These sherds have been listed on Table 1 as late period majolica. One sherd is shown in Figure $6, \mathrm{~h}$.

\section{WHITE PASTE EARTHENWARE}

A total of $194(230.12 \mathrm{~g})$ white paste earthenware sherds was recovered. Most of the hard white paste or refined earthenware in the collection are from the 19th-century and are associated with European and eastern United States industrial centers. Most of the Mexican and local tradition ceramics are made of a relatively soft cream or reddish paste which helps to separate them from the later period hard paste whitewares. The differences within the hard paste category are dealt with in terms of decoration, just as in the previous majolica category. The reason for this is that the major varieties of hard white paste wares can be extremely difficult to separate with accuracy. These varieties are creamware, pearlware, and ironstone (Miller 1980:2; Lamb and Beavers 1983:46-47).

Nine sherds (14.33 g) of banded slip wares are included in the white paste earthenware category. One sherd is shown in Figure 6,i. Banded slip wares are whitewares that have been decorated with regular horizontal bands. The bands are painted under a glaze. Banded wares were produced in a wide variety of vessel shapes and decorative motifs from the 1780s to the mid-19th century. Banded slip wares have been recovered from the Alamo (Greer 1967:33, Fig. 14) and Mission San José (Clark 1974:93). Banded slip ware enjoyed a peak 
of popularity from 1800 to 1850 . This ware was initially mass produced for export in England in the first quarter of the 19th century. By the mid-1830s, it was a common manufacture for British and American potteries (Schuetz 1969:17-18; Robacker and Robacker 1978:24; Miller 1980:3). Banded slip ware also is referred to in the literature as dipped ware. The term "mocha" also is used, but is confusing because mocha also is used to describe a specific decorative motif. Further work is needed to clearly define the terms mocha and banded slip.

Among the white paste earthenwares are 13 sherds $(12.39 \mathrm{~g})$ of transfer print wares. Of these, six (5.45 g) are of the flow blue transfer print variety. One body sherd with a blue design is shown in Figure 6,k. Flow blue was increasingly popular during the late 1840 s but was gradually replaced by plain whitewares beginning in the $1850 \mathrm{~s}$. By the 1870 s, transfer print wares, including flow blue, were in very limited use (Miller 1974:201).

The other transfer ware sherds in the collection have predominantly blue-printed patterns (Fig. 6,j). Blueprinted transfer designs were available from the 1790s. Designs printed in other colors, such as red and green, were introduced ca. 1800-1820s (Beavers 1976:5-6). Miller (1974:201) indicates that these wares were introduced on a large scale in the 1830s. Red and blue transfer prints were the most commonly available types during the 1840s (Miller 1974:209; Beavers 1976:9). Hanson and Hsu (1975:74-75) indicate that the transfer wares were available throughout the 19 th century and only began to decline during the $1860 \mathrm{~s}$. Transfer print wares have an early date of the 1790 s and a peak of popularity in the 1840 s. By the 1850 s, transfer wares were competing with the undecorated whitewares which were beginning to dominate the market.

Hand-painted wares are represented by 43 sherds $(33.17 \mathrm{~g}$ ) in the collection. One sherd is shown in Figure 6,n. Dating hand-painted wares is a problem. Miller (1980:28) states that hand-painted wares were not common in the 19th century. Apparently hand-painted bowls and cups were available. The term "hand painted" also is a rather broad term. It is usually separated from sponged designs that often contain hand painting as well. Hand-painted wares, as used here, are brush painted, hard white paste wares. The decorative motifs include polychrome floral designs and geometric designs, such as banding. Hand-painted wares are a poor dating tool. Further work is needed to more clearly define "hand-painted" categories of ware.

Fifteen sherds of sponged wares were recovered. One body sherd with a red design is shown in Figure 6,l. Sponge-painted wares were popular from the 1800s through the 1850s. Mass produced in England for export, they enjoyed a peak of popularity during the 1830s and 1840s. One of the sherds is a red "spatter" ware, a variation of the sponge-painting technique.

Nine sherds $(5.07 \mathrm{~g})$ in the white paste earthenware category are cut sponge-printed wares. These wares are decorated with a printing technique which uses sponges cut to a specific shape. The cut sponge-printing technique was not in wide use until ca. 1845 (Robacker and Robacker 1978:32, 80).

Three edge-decorated ware sherds $(8.01 \mathrm{~g})$ are included among the white paste earthenware artifacts. Miller $(1973: 6,8 ; 1974: 203-204)$ dates blue edge-decorated ware from the 1790 s through the 1850 s. These wares were mass produced in England for export.

The remaining sherds of the white paste earthenware category are 101 fragments $(137.53 \mathrm{~g})$ of undecorated whiteware. This group of sherds is second only to Goliad ware in count and weight and is the dominant late 19th-century group of ceramics represented in the collection. Undecorated whiteware is a horizon marker for the 1850s (Miller 1980:4, 29). A. Fox (personal communication) suggests that undecorated whitewares replaced other hard white paste earthenware ceramic types in Texas in the 1850s.

\section{OTHER LATE 19TH-CENTURY/EARLY 20TH-CENTURY CERAMICS}

Among the artifacts collected were two sherds (65.08 $\mathrm{g}$ ) of a brown ceramic drain pipe. Common during the early 20 th century, the pipe is molded and was used for water lines. 
A ginger beer bottle of the type which was mass produced in England and Scotland and exported to America from the 1860 s to the 1880 s is represented by one sherd. England was the main exporter of the small ginger beer bottles (Kendrick 1967:19). Ceramic bottles for beer and other liquids were in use until the 1880s, when glass bottles were mass produced by the semiautomated bottle-making process (Kendrick 1967:19).

Six sherds (14.61 g) are of a type of stoneware with an Albany slip. One sherd with an Albany slip on one side is shown in Figure 6,0. Made during the last quarter of the 19th century, the production of these thickwalled, utilitarian wares was discontinued during the first 20 years of the 20th century. Albany slip fires to a deep brown or reddish brown. In the 1967 excavations at Mission San Juan Capistrano, sherds with this glaze were identified as a type produced at the Elmendorf kiln between 1885 and 1916-1917 (Schuetz 1969:23). The material from these excavations could be from the same manufacturer.

Nine sherds $(2.91 \mathrm{~g})$ of yellow ware were collected. Yellow wares are thick-walled, utilitarian, and made of a hard buff or yellow paste. A hard vitreous yellow slip seals the body paste. One rimsherd from a large jar or crock is shown in Figure 6,m. This type of ware was widely available in the United States during the 1890s and early 20th century. It is not thought to be locally made (A. Fox, personal communication).

\section{METAL ARTIFACTS}

A total of 98 metal fragments $(960.39 \mathrm{~g})$ was recovered. The metal artifacts are identified as round wire nails; square cut nails; fence staples; other construction hardware, such as screws and door hinges; wire; personal items, such as jewelry; and other miscellaneous, unidentified fragments.

Fifty-three nails and/or nail fragments (no weight taken) were recovered. Two types of nails were found, round wire and square cut. Thirty-eight round wire nails and nail fragments were recovered. Thirteen of these were complete and so could be sized. The sized nails represent a wide range of common sizes: $4 \mathrm{~d}$, the smallest in the collection; 8d (Fig. 7,g); 16d; and even 40d, the largest in the collection. The round wire nails do not include any roofing, finishing, or other types of nails. Round wire nails began to supersede square cut nails in popularity during the 1880s (Nelson 1968:7).

Twenty-five square cut nails and fragments were found. One square cut nail fragment is shown in Figure 7 ,d. The square cut nails are thought to be machine made and date to no earlier than 1836 (Nelson 1968:7). Two common $7 \mathrm{~d}$ and one common $4 \mathrm{~d}$ square cut nails are in the collection. The remainder of the square cut specimens have headless shanks or have common heads, but are fragmentary and unidentifiable as to size. No finishing or other types of square cut nail were recognized.

Three very corroded and encrusted fragments of what was apparently a large spike (not shown) were recovered. It is not possible to determine if these are handmade or machine made. Another large spike is apparently a railroad spike and is machine made (not shown). In addition, excavators recovered a common wood screw and a corroded piece of iron hasp for a door (Fig. 7,k).

A tentatively identified cabestrillo (Fig. 7,f), which is part of a bridle chain, made in a style associated with Spanish and Mexican colonial horse equipment was recovered. A similar cabestrillo was recovered at Rancho de las Cabras (Ivey 1983:21). Other metal artifacts are a crown bottle cap fragment, a handle of an eating utensil such as a fork or spoon, and aluminum foil fragments.

Only two types of wire are represented in the collection, and these came only from the top excavation levels. One of the wire fragments is light gauge wire from a wine bottle corker (Fig. 7,e). Several different fragments of light gauge wire were collected.

The other wire type is represented by a piece of late 19th-century or early 20th-century manufactured barbed wire (Fig. 7,j). The design or pattern of the barbed wire is similar to the Glidden style which was widely available in the 1880s (Abernathy and Kennedy 1979:198). 
Figure 7. Metal and Lithic Artifacts.
a, religious medal, Unit F, Level 2;
b, brass stamped button cover, Unit G, Level 4;
c, pendant, copper with glass set, Unit G, Level 4;
d, square cut nail fragment, common head, Unit C, Level 2;
e, bottle cork wire, representative of light gauge wire, Unit C, Level 1;
f, tentatively identified cabestrillo, Unit G, Level 4;
$\mathrm{g}$, round wire nail, common head, 8d, Unit E, Level 2;
h, rechen pfennig, Unit G, Level 5 ;
i, pencil eraser collar/holder, Unit C, Level 2;
j, Glidden-style barbed wire, representative of heavy gauge wire, Unit G, Level 2;
$\mathrm{k}$, iron door hasp, Unit $\mathrm{F}$, Level 2;
1, Guerrero point, Unit F, Level 3;
$\mathrm{m}$, Guerrero point, Unit G, Level 5 ;
$\mathrm{n}$, decorticate chip, possible gunflint debitage, Unit C, Level 1;
o, primary platform flake, Unit $\mathrm{G}$, Level 4;
p, primary platform flake, Unit G, Level 3;
q, primary platform flake, Unit $G$, Level 4;
$r$, corticate chip, burned, Unit C, Level 3;
s, primary platform flake, Unit G, Level 4 . 


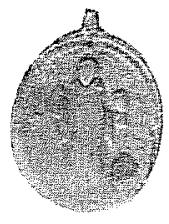

a

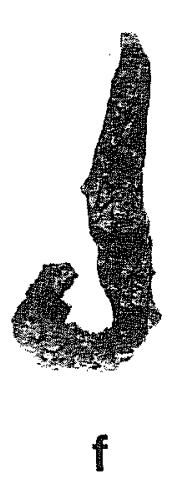

.

I

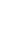

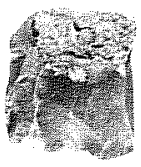

q

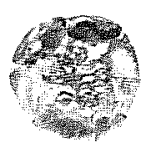

b

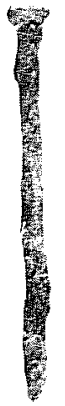

g

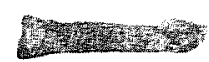

d

c

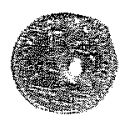

h

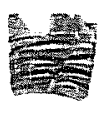

i

5

j
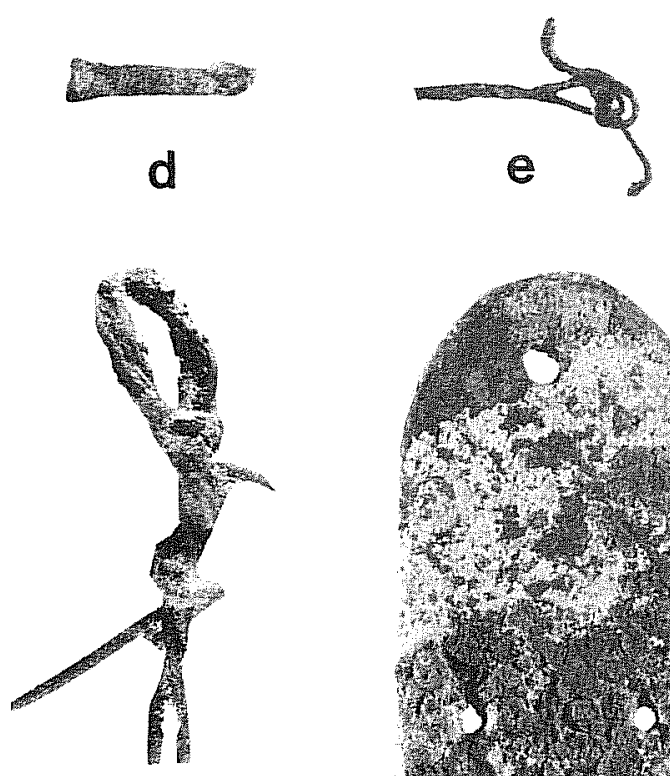

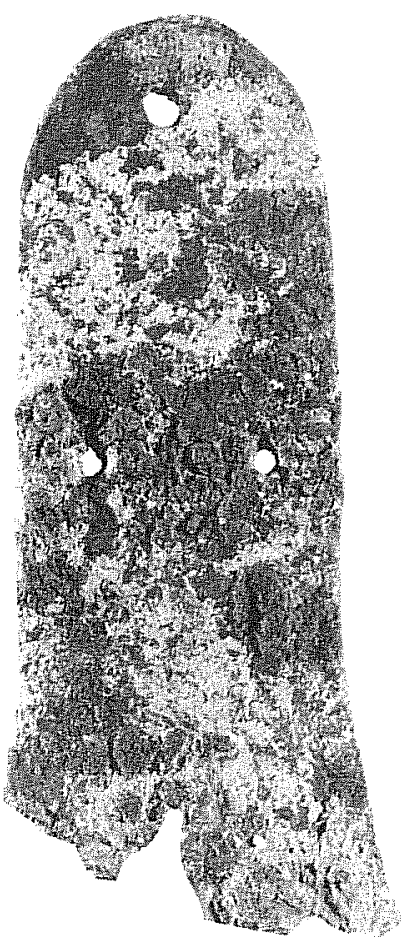

k

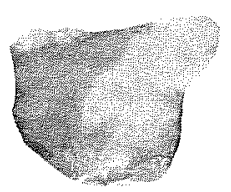

p

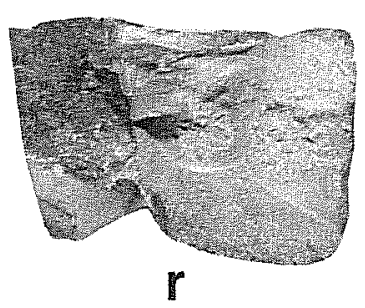

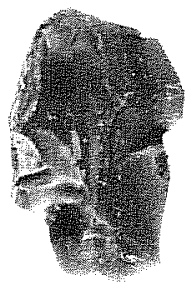

o

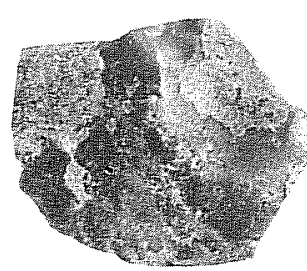

$S$

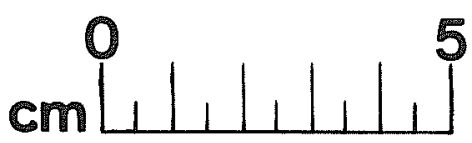


Five specimens of fence staples were found. These were manufactured in the 20th-century. Greer (1967:72) identified this type of fence staple during excavations at the Alamo.

Two coins were recovered. One is a 1969 " $\mathrm{D}$ " series Lincoln penny (not shown), and the other is a pfennig (Fig. 7,h). The pfennig is a thin sheet of stamped brass or copper. One face of the coin is mostly obscured by encrusted rust. The face which is legible shows a lion passant (on all fours) and regardant (looking at the viewer). Below the lion are three visible letters, possibly a Latin abbreviation, "I.A.D." Other letters are visible. These are located from the viewer's left to right along the outer and top border of the face with the lion figure. These letters are "RECHEN PFENNIG." The rechen pfennig or reckoning pfennig was used as a counter with a marked board. The counters were produced between 1780 and 1830 and were always made of brass. This particular counter is thought to have been produced by the Lauer or Krauwinkel mints in Nuremburg (Richard E. Ahlborn, personal communication). The coin counter has been perforated from back to front.

An item identified as a pendant is made of copper with a setting of clear cut or ground glass (Fig. 7,c). The object is thought to be part of a necklace. Schuetz (1969:44 and Plate 20,G, H) identified two similar objects set with colored glass "stones" in the 1967 excavations at Mission San Juan Capistrano. This type of jewelry was a common gift by the priest to the Indians at the missions (A. Fox, personal communication).

A stamped brass item (Fig. 7,b) is the face piece of a compound button. The backing piece was not found. The stamped face of this specimen bears a floral design surrounded by radiating lines. Schuetz (1969:46-47) states that lead-backed compound buttons were manufactured between 1790 and 1800 . They were made with a stamped piece of copper or brass and were backed with a lead "plate" mounted with a shank. However, a compound button called a "picture" button was made between 1850 and 1900. This latter type was made by sandwiching fabric between two copper discs, one of which was stamped with a design. Without the backing piece, this button face is not datable with certainty. At this writing, the artifact is thought to be representative of the earlier manufacturing type. The artifact was found in a Spanish colonial context.

A copper or brass religious medal (Fig. 7,a) was found in the second excavation level. The medal is stamped on one side and shows a saint figure. The figure is a human in Franciscan robes, standing and facing the viewer. The figure's right hand holds a Latin cross, and the figure's left hand holds a chalice or a goblet. Stylized halo lines radiate from the head. The figure is apparently bearded. Most of the letters on the face of the medal are not legible. The following letters are visible, but are not part of the same word: C.A.V.I. (or L.) and S. These letters might represent a set of proper names or a set of Latin abbreviations. The medal has a design on only one face; the other face is blank. The suspension loop is broken off, but enough is left to determine that the loop was perpendicular to the face of the medal. The medal was possibly stamped but could also have been made in a two-piece mold.

Schuetz (1969:44, Plate 21, H, H') recovered a similar artifact in the 1967 excavations at Mission San Juan Capistrano. Religious pendants with cross-set hanging loops are dated 1750/1760 through 1810/1820. It is possible that the barely legible letters form the name "S. Luis." San Luis Bertran was a 16th-century Spanish Dominican who served in Mexico. His symbolic attributes are a crucifix and a serpent in a cup. The chalice shows no obvious signs of a serpent; one is not visible under low-power magnification. A chalice without such unexpected contents as serpents could also represent Saint Benedict. Another San Luis is San Luis Gonzaga, an Italian Jesuit. The fact that the back face of the pendant is blank is considered unusual. The back shows no sign of worn down designs (Richard E. Ahlborn, personal communication).

A copper pencil eraser collar (Fig. 7,i) also was found in the rocky layer. These were manufactured in the late 19 th century and into the 20 th century.

\section{GLASS}

A total of 206 glass fragments $(282.21 \mathrm{~g}$ ) was recovered, all very small in size, chipped, and shattered. Only two pieces were found which could be considered vessel diagnostics. These two sherds are mouth/lip 
fragments. One, found in excavation Level 5, is dated to the last half of the 19th century. It is made of green glass with numerous internal flaws such as bubbles and internal striations. Horizontal surface striations are faintly visible. This suggests the use of a lipping tool to apply a brandy or oil bottle finish. Lorrain (1968:40) states that the lipping tool process was in use ca. 1850. Newman (1970:73) asserts that the popularity of lipping tools was high from 1850 through 1870.

The other diagnostic glass mouth/lip fragment is a clear soda bottle lip. This piece is made with a modern manufacturing process and is a 20th-century artifact.

Since only two pieces of glass were diagnostic, the other fragments were separated by color categories. A quick examination of the fragments was conducted to determine manufacturing technique, if possible. The attributes searched for were flaws and striations internal to the glass such as uneven, varying thickness; foreign inclusions; and rough surface texture.

Seventy-three fragments ( $104.62 \mathrm{~g})$, approximately $65 \%$ of the total glass collection, have been identified as 19 th-century hand- or mold-blown bottle glass. This material is given a general manufacturing cutoff date of the late 1850s. No glass artifacts were found below the $50-\mathrm{cm}$ level. Of the 73 glass bottle fragments, 64 were located in excavation Levels 2 and 3. The glass artifacts represent a date range of the late 19th century through the 20 th century. Green flawed 19 th-century bottle glass dominated the collection. The remaining glass fragments were from modern mass-produced vessels or were unidentifiable.

\section{LITHICS}

Of the 55 chert specimens $(215.92 \mathrm{~g})$ recovered during these excavations, only two are diagnostic artifacts. They are bifacially worked triangular projectile points (Fig. 7,1,m), that fit Fox's (1979:25-26) Group 4 biface category. Hester $(1980: 104,106)$ identifies these as Guerrero points. Guerrero points were also found at Rancho de las Cabras (Ivey 1983:61, Fig. 11). Schuetz (1969:71-72) recovered this point type during the 1967 excavations at Mission San Juan Capistrano.

The majority of lithics were not recognizable as tools and are considered debitage as the result of manufacturing and resharpening/reshaping techniques. Fox's (1979:11, Fig. 2) classification system was used to identify and catalog the debitage materials. These categories are applied for descriptive purposes and are tentative. Categories are primary platform flakes and corticate and decorticate chips (Fig. 7,0-s).

Five of the decorticate chips may be debitage from gunflints or strike-o-lites (Fig. 7,n). These represent either reshaping or initial manufacture activities. Since the pieces are very small decorticate chips, this identification also is tentative.

The Guerrero points occurred in strata II and III. The lithic manufacturing debitage and the platform flakes were scattered throughout the culture-bearing deposits as were the chips. The lithics represent a limited part of the whole artifact assemblage. The position of the Guerrero points in the excavation strata lends support to the dating of the lower strata to mission period usage.

\section{$\underline{\text { PLASTIC }}$}

Several fragments of plastic were collected in the upper two excavation levels of the units. These fragments are from plastic eating utensils, specifically a fork and a spoon.

\section{BONE}

No bone artifacts were found. Much of the bone $(9.85 \mathrm{~kg})$ from these excavations is extremely fragmented in very small pieces and splinters. Larger, more robust pieces of bone, such as vertebrae and long bone 
articulation surfaces, were identifiable as cow and sheep or goat. The very small fragments are not diagnostic. Some burned bone was recovered (10 fragments, $21.91 \mathrm{~g}$ ), but this material is also unidentifiable.

The recognizable pieces of bone could give some indication of butchering and meat consumption habits, but the very small pieces possibly represent rib bones and other more delicate bones. Since most of the bone is currently unidentifiable, no further analysis is planned at this time. Analysis of butchering habits must await further comparisons with known techniques.

\section{SHELL}

Seven mussel shell fragments ( $12.66 \mathrm{~g})$ and four unidentified shell fragments $(6.4 \mathrm{~g})$ were recovered. Only two individual fragments are positively identified as umbos from bivalves.

\section{DISCUSSION}

During the Spanish colonial period, trade and transportation networks for the San Antonio River missions were with central Mexico. By the later part of the 19th century, people were buying different types of goods: central Mexican wares were replaced by hard white paste wares associated with European manufacturing and eastern United States trade centers.

The presence of transfer, hand-painted, sponged, and other "Anglo- European" wares in the upper deposits does not necessarily indicate that trade networks linking Mission San Juan Capistrano to central Mexico were abolished, or even significantly changed. The presence of these wares does establish that a different set of tastes and preferences was beginning to be reflected in the consumption patterns and economy of the mission during the second half of the 19th century.

The presence of the Albany slip sherds reflects the participation of the dwellers of Mission San Juan Capistrano in a growing local economy at the turn of the century. This ware type is thought to be from the Elmendorf pottery located nearby. There is a continued presence of later period undecorated majolica ware in the upper deposits. This indicates that an active trade with the central Mexican potteries was ongoing. The nature and extent of this local trade and its impact on the long-established Mexican trade have not yet been examined in detail.

The ceramics were used as the primary resource in dating the layers of deposition. The other artifacts were used to support the proposed dates derived from the ceramics. The lithic materials and metal artifacts provide only broad insights into the economic life of the mission.

Stone tools were used in the Spanish colonial period. Metal was rare and expensive. The presence of the two Guerrero points in Spanish colonial context demonstrates this practice. The other lithic material is tentatively identified as debitage from tool manufacturing and resharpening/reshaping activities.

The majority of the metal artifacts recovered are modern nails and wire. Machine-made square cut nails were not available before 1836, and wire nails were not available until the 1880s (Nelson 1968:7). The fact that the metal artifacts are mostly late 19th-century and 20th-century manufactured items reflects the chronic shortage of metal in the Spanish colonial and Republic periods.

A coin shortage is common in nonindustrial agricultural based economics (Braudel 1979:439, 441). Since coin was so rare, even a damaged (e.g., perforated) "foreign" coin or counter had value such as the one recovered.

The pendant with a glass set and stamped picture button are part of a very limited set of luxury trade items. This pendant and the stamped face of the button represent a consumer demand for affordable and attractive adornment. The pendant possibly represents jewelry brought by the priests for Indian trade. 
The majority of the artifacts can be considered utilitarian. The central Mexican ceramics include only a handful of sherds which represent luxury wares, such as Tonala burnished ware. The hard white paste wares reflect this utilitarian versus luxury pattern. Flow blue transfer ware was a more expensive ware and so is considered by archaeologists and historians to be a higher status ware than "regular" transfer print wares (Miller 1980:4,29). Flow blue is the only conclusively identified "luxury" component of the hard paste wares. No porcelain was identified during these excavations.

The amount of bone versus the paucity of shellfish remains indicates that the mission dwellers did not utilize shellfish to any extent. There was an overwhelming dependence on sheep/goat and cow. It is possible that the lack of mussel shells in the deposits represents a sampling bias. The shells may not have been dumped in this area of the midden. A wider excavation area is needed to determine the consumption of mussels.

Usage of an area as a dump was fairly intensive during the Spanish colonial period. The intensity of the trash dumping diminished during the later part of the 19th century. Fewer faunal materials are included in the later period assemblage. The midden area was capped by the caliche and rock layer which marked the end of the midden usage in the area. Some trash was still dumped here, however. The rocky layer included some bone and was mixed with very shattered, fragmented 19 th-century and 20th-century glass, undecorated whiteware, wire, and most of the nails. This rocky layer may be material from the WPA restoration activities in the 1930s.

The economic life of the mission and its relations to a greater community is an area in which further study is needed. Understanding these interrelationships will provide interesting and perhaps useful insights into the problems faced by a growing San Antonio.

\section{CONCLUSIONS}

Unlike Schuetz' "Area B" midden on the south side of the mission compound (see Fig. 1), the material recovered during these excavations and monitoring operations was from undisturbed context. The artifacts were recovered in recognizable cultural strata. The changes in actual soil strata, however, were very limited in the artifact-bearing deposits. All of the cultural material was apparently dumped on the ground surface, and natural processes were allowed to scatter and bury the material.

The materials in the midden at Mission San Juan Capistrano are spread in layers consistent across the entire test area. The midden deposits might be thicker nearer the walls. These findings challenge the idea that pits were dug for trash disposal. The possibility of trash buried in pits near the gate has not been disproved; however, this excavation does not support the idea that the practice was in use at this site. Certainly, at a distance of 12 feet north of the wall, no excavated pits were located. How far north of the wall the midden extends is also unknown.

These excavations determined that any possible structures do not exist outside the compound walls and 12 feet north of the wall. However, if any trenching for construction is to be done closer to the compound wall, archaeological testing and monitoring are recommended. The possibility of locating large structures is eliminated, but a shed or an oven or even a small jacal may have been located outside of the wall.

The area of recovery of the artifacts indicates the presence of an extensive area for trash dumping outside the north wall. Any further activities in the area will have an impact on this midden which appears to be largely undisturbed at present.

The intensity of trash dumping decreased during the 19th century. The dumping ceased by the 1930s, and the area became part of a roadway. The last significant change in the area was the laying of the City Water Board pipeline. This area is now protected from vehicular traffic, and is a valuable part of the cultural resources preserved at the Mission San Juan Capistrano site. 


\section{REFERENCES CITED}

Abernathy, F. E. and R. Kennedy

1979 Built in Texas. Publication of the Texas Folklore Society XLII. E. Heart Press, Waco.

Almaraz, F. D.

1982 Land Tenure Study of the San Antonio Missions. Manuscript on file at the San Antonio Missions National Historical Park, San Antonio.

Beavers, R. C.

1976 A Seriation of Historic Ceramics in the Midwest, 1780-1820. Paper presented at Joint Plains Anthropological Conference.

Braudel, F.

1979 The Structures of Everyday Life; The Limits of the Possible: Civilization and Capitalization 15th-18th Century. Vol. 1. Harper and Row, New York.

Environmental and Cultural Services, Inc.

1982 Form and Environment: Historical and Cultural Landscape Study of the San Antonio Missions. Environmental and Cultural Services, Inc., San Antonio, Texas. Submitted to the United States Department of the Interior, National Park Service, San Antonio Missions National Historical Park, Contract No. 7600-1-001.

Campbell, T. N. and T. J. Campbell

1985 Indian Groups Associated with Spanish Missions of the San Antonio Missions National Historical Park. Center for Archaeological Research, The University of Texas at San Antonio, Special Report 16.

Cisneros, J. A.

1980 San Antonio Missions National Historical Park, San Antonio, Texas. Statement for Management. United States Department of the Interior, National Park Service, San Antonio, Texas.

Clark, J. W.

1974 Mission San José y San Miguel de Aguayo: Archeological Investigations. Office of the State Archeologist, Report 29.

Eaton, J. D.

1980 Excavations at the Alamo Shrine (Mission San Antonio de Valero). Center for Archaeological Research, The University of Texas at San Antonio, Special Report 10.

Ewers, J. C.

1973 The Influence of Epidemics on the Indian Populations and Cultures of Texas. Plains Anthropologist 18(60):104-105. 
Fladmark, K. R.

1978 A Guide to Basic Archaeological Field Procedures. Simon Fraser University Press, Burnaby, British Columbia.

Fox, A. A., F. A. Bass, Jr., and T. R. Hester

1976 The Archaeology and History of Alamo Plaza. Center for Archaeological Research, The University of Texas at San Antonio, Archaeological Survey Report 16.

Fox, D. E.

1979 The Lithic Artifacts of Indians at the Spanish Colonial Missions, San Antonio, Texas. Center for Archaeological Research, The University of Texas at San Antonio, Special Report 8.

Goggin, J. M.

1968 Spanish Majolica in the New World: Types of the 16th-18th Centuries. Yale Department of Anthropology, Publications in Anthropology 72.

Greer, J. W.

1967 A Description of the Stratigraphy, Features, and Artifacts from an Archeological Excavation at the Alamo. State Building Commission Archeological Program, Report 3.

Hafernik, D. and A. A. Fox

1984 Archaeological Testing of Proposed Sewer Line Location at Mission San José. Center for Archaeological Research, The University of Texas at San Antonio, Archaeological Survey Report 138.

Hanson, L. and D. P. Hsu

1975 Casemates and Cannonballs, Archeological Investigations at Fort Stanwix, Rome, New York. United States Department of the Interior, National Park Service, Publications in Archeology 14. Washington, D.C.

Hemion, R. H.

1983 Field and Laboratory Handbook. Southern Texas Archaeological Association, Special Publication 2.

Hester, T. R.

1980 Digging into South Texas Prehistory. Corona Publishing Company, San Antonio, Texas.

Ivey, J. E.

1983 Archaeological Testing at Rancho de las Cabras, 41 WN 30, Wilson County, Texas, Second Season. Centerfor Archaeological Research, The University of Texas at San Antonio, Archaeological Survey Report 121. 
Ivey, J. E. and A. A. Fox

1981 Archaeological Survey and Testing at Rancho de las Cabras, Wilson County, Texas. Center for Archaeological Research, The University of Texas at San Antonio, Archaeological Survey Report 104.

Ivey, J. E. and M. B. Thurber

1984 The Missions of San Antonio: A Historic Structures Report and Administrative History: Part 1-The Spanish Colonial Missions. National Park Service, Southwest Cultural Resources Center. Draft report on file at the Center for Archaeological Research, The University of Texas at San Antonio.

Kendrick, G.

1967 Bottle Fragments Betray Age of Historical Sites. El Palacio 74(2):19-24.

Lamb, T. R. and R. C. Beavers

1983 Archaeology of the Stableyard Complex, Hermann-Grima House, New Orleans, Louisiana. Archaeological and Cultural Research Program, Report 7. University of New Orleans.

Lorrain, D.

1968 An Archaeologists's Guide to Nineteenth Century American Glass. Historical Archaeology 2:35-44.

May, R. V.

1975 Mexican Majolica in Northern New Spain: A Model for Interpreting Ceramic Change. Master's thesis presented to the faculty of San Diego State University. Manuscript on file at the Center for Archaeological Research, The University of Texas at San Antonio.

Miller, G. L.

1973 Some Notes on Blue Edgeware. Paper presented at the Society for Historical Archaeology Meeting, St. Paul, Minnesota. Copy on file at the Center for Archaeological Research, The University of Texas at San Antonio.

1974 A Tenant Farmer's Tableware: Nineteenth Century Ceramics from Tabb's Purchase. Maryland Historical Magazine 69(2):197-210.

1980 Classification and Economic Scaling of 19th Century Ceramics. Historical Archaeology 14:141.

Munsell Soil Color Charts

1975 Division of Killmorgen Corporation, Baltimore, Maryland.

Nelson, L. H.

1968 Nail Chronology as an Aid to Dating Old Buildings. American Association for State and Local History, Technical Leaflet 48. Nashville, Tennessee. 
Newman, T.S.

1970 A Dating Key for Post 18th Century Bottles. Historical Archaeology 4:70-75.

Robacker, E. F. and A. F. Robacker

1978 Spatterware and Sponge: Hardy Perennials of Ceramics. A. S. Barnes and Co., London.

Ruecking, F. H., Jr.

1953 The Economic System of the Coahuiltecan Indians of Southern Texas and Northeastern Mexico. The Texas Journal of Science 5(4):480-498.

1954 Ceremonies of the Coahuiltecan Indians of Southern Texas and Northeastern Mexico. The Texas Journal of Science 6(3):330-339.

1955 The Social Organization of the Coahuiltecan Indians of Southern Texas and Northeastern Mexico. The Texas Journal of Science 7(4):357-388.

Scurlock, D. and D. E. Fox

1977 Archeological Investigation of Mission Concepcion, San Antonio, Texas. Office of the State Archeologist, Report 28.

Schuetz, M. K.

1968 The History and Archeology of Mission San Juan Capistrano, San Antonio, Texas. Vol. 1: Historical Documentation and Description of the Structures. State Building Commission Archeological Program, Report 10.

1969 The History and Archeology of Mission San Juan Capistrano, San Antonio, Texas. Vol. II: Description of the Artifacts and Ethnohistory of the Coahuiltecan Indians. State Building Commission Archeological Program, Report 11.

Southwest Regional Office, National Park Service

1981 Environmental Assessment: General Management Plan/Development Concept Plan of the San Antonio Missions National Historical Park, San Antonio, Texas.

Taylor, A. J. and A. A. Fox

1985 Archaeological Survey and Testing at Rancho de las Cabras, 41 WN 30, Wilson County, Texas, Fifth Season. Center for Archaeological Research, The University of Texas at San Antonio, Archaeological Survey Report 144.

Taylor, F. B., R. B. Hailey, and D. L. Richmond

1966 Soil Survey of Bexar County, Texas. United States Department of Agriculture, Soil Conservation Service, in cooperation with the Texas Agricultural Experiment Station, Series 1962(12).

Weddle, R. S. and R. H. Thonhoff

1976 Drama and Conflict: The Texas Saga of 1776. Madrona Press, Inc., Austin. 
